\title{
A 60 kWe Solar Organic Rankine Cycle (SORC) Power Generation in Thailand
}

\section{Sorawit Sonsaree, Eakpoom Boonthum}

Faculty of Industrial Technology, Pibulsongkram Rajabhat University, Phitsanulok, Thailand

Correspondence Author: Sorawit Sonsaree, Faculty of Industrial Technology, Pibulsongkram Rajabhat University, Phitsanulok, Thailand

Received date: 11 June 2019, Accepted date: 28 July 2019, Online date: 8 August 2019

Copyright: (C) 2019 Sorawit Sonsaree, Eakpoom Boonthum. This is an open-access article distributed under the terms of the Creative Commons Attribution License, which permits unrestricted use, distribution, and reproduction in any medium, provided the original auth or and source are credited.

\begin{abstract}
Solar energy is one of the renewable energies that has been proved to be a practical way to solve the present energy crisis and achieve sustainable development. However, in Thailand, the Concentrating Solar Power (CSP) technologies are inappropriate for power generation because the annual direct or beam solar radiation is low. In this study, the concept of a solar Organic Rankine Cycle (SORC) system for power generation with temperature below $100{ }^{\circ} \mathrm{C}$ is proposed. The system is analyzed by using a $60 \mathrm{~kW}_{\mathrm{e}} \mathrm{ORC}$ power generation with R-245fa as working fluids in combination with solar water heating system (SWHS). Compound Parabolic Concentrating (CPC) solar collectors were used to generate heat. These systems were mathematically modelled and simulated to evaluate the maximum power output, the $\mathrm{CO}_{2}$ emission, and levelized cost of electricity (LCOE). Bangkok represented as the central part of Thailand were taken as the weather data of the simulations. The results found that, a SORC power plant is appropriate for below $100{ }^{\circ} \mathrm{C}$ heat source. The $0 R C$ system is a good solution for power generation from low-temperature heat source. Moreover, when 1,680 units of CPC solar collectors combined with a $60 \mathrm{~kW}_{\mathrm{e}}$ ORC power generation and size of the thermal energy storage (TES) of 50,000 liters, the system were the lowest LCOE of $0.915 \mathrm{USD} / \mathrm{kWh}$, the system can generate the power output of $159.9 \mathrm{MWh} /$ Year and can reduce $\mathrm{CO}_{2}$ emission of $88 \mathrm{Ton} \mathrm{CO}_{2}$ eq./Year.
\end{abstract}

Keywords: Solar water heating system; Solar Organic Rankine Cycle (SORC) system; Electrical power generation; Levelized Cost Of Electricity (LCOE)

\section{INTRODUCTION}

The utilization of fossil fuels for power generation has led to many environmental problems. In currently, solar energy has been growing attention and traction. It is a resource that never depletes, therefore its worth to develop and explore and it can help to move from fossil fuel technologies to renewable technologies [1]. Thailand is a country with direct or beams normal solar radiation in the range of $1,350-1,400 \mathrm{~kW} / \mathrm{m}^{2}-$ Year [2], making it inappropriate for the use of Concentrating Solar Power (CSP) technologies that require radiation above 1,500 kWh/m²-Year [3-5]. In recent years, power systems with small-scale Organic Rankine Cycle (ORC) have expanded focus due to their require the low-temperature heat source, high efficiency, small impact on the environment [6], and active way of converting solar thermal energy into electricity [7].

Moreover the ORC power technology is suitability to be applied on decentralized small-scale power plants [8-10]. For solar water heating system (SWHS) combined with the ORC power generation, Wang et al. [6,11] proposed a regenerative ORC to utilize the solar energy by using flat-plate solar collectors to collect the solar radiation. The results indicate that when install a thermal storage tank, the system can achieve a continuous and stable operation over a long time. Sonsaree et al. [12] proposed a system that utilizes low-temperature heat (under $100{ }^{\circ} \mathrm{C}$ ) from solar energy to generate electricity by a small-scale ORC system. The system is analyzed using three different capacities of the ORC system with R-245fa $\left(20,40\right.$, and $\left.60 \mathrm{~kW}_{\mathrm{e}}\right)$ in combination with SWHS. Flat-plate, evacuatedtube, and Compound Parabolic Concentrating (CPC) solar collectors were used to generate heat to supply directly to the system. Spayde et al. [13] presented a combined Solar Organic Rankine Cycle (SORC) with electric energy storage (EES) or the SORC-EES system to supply electricity to commercial buildings including a large office, a small office, and a full service restaurant. The results found that the system is able to satisfy $11 \%, 13 \%$, and $18 \%$ of the electrical demand for the large office, the small office and the restaurant, respectively.

From the literature review above, it can be noted that the CSP technologies are inappropriate in Thailand. Despite the fact that ORC system have been extensively applied for power generation from low-temperature heat source. The main objectives of this research are:

Develop a mathematical model and simulate the performance of the SORC power generation system based on the power output, the $\mathrm{CO}_{2}$ emission, and the economic analysis in terms of Levelized cost of electricity (LCOE),

Obtain the optimal number of solar collectors, size of the thermal energy storage (TES) for the maximum power output in each month.

\section{System Simulation and Descriptions}

The main components of the SORC power system shown in Fig. 1 are the solar collectors, the ORC power generation, the cooling tower, the storage tank, and the collectors' pump. In the system operation as shown in Fig. 2 (Solar collector field (A) is the maximum number of solar collectors that suitable for hot water production in each month, and Solar collector field (B) is the number of solar collectors was not used for hot water production in the solar collectors field (A)): in the day time or sunrise, the low-temperature hot water from the TES-I and TES-II ( $\mathrm{T}_{\text {Coll, } \mathrm{i}-\mathrm{I}}$ and $\mathrm{T}_{\mathrm{Coll}, \mathrm{i}-\mathrm{II}}$ ) is pumped by the collector pump (Collector pump-I and II, respectively), to the solar collector field (Field A and B) to produce the high-temperature hot water. At this step, the hot water flow rate that supplied to the solar collector field (Field A and B) is adjusted to achieve a hot water temperature in the range of 70 to $95{ }^{\circ} \mathrm{C}$. After that, the high-temperature hot water from the 
TES-I is supplied to the ORC for power generation. At the night time or sunset, the high-temperature hot water from the TES-II is supplied to the ORC for power generation.

Fig. 1: The SORC power generation system
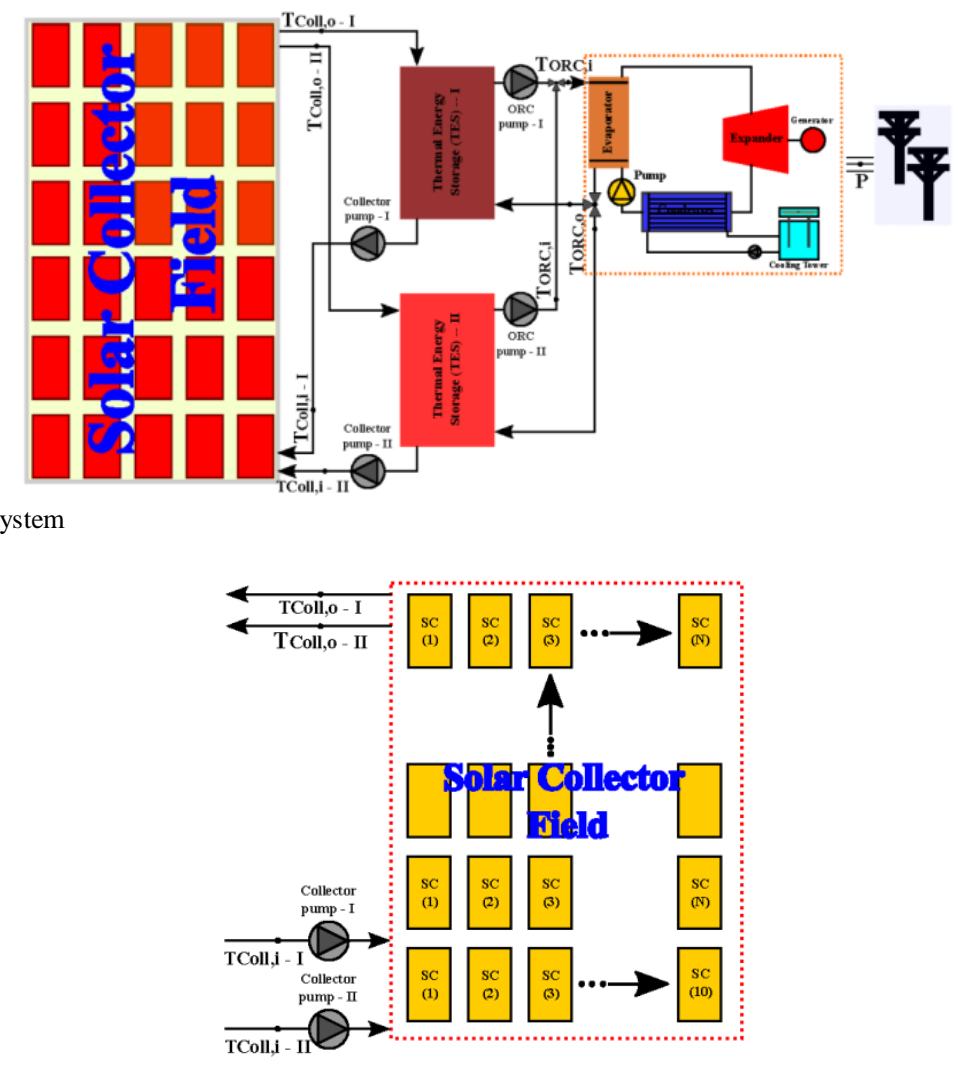

(a) Solar collector field (Total number of the solar collectors installation)

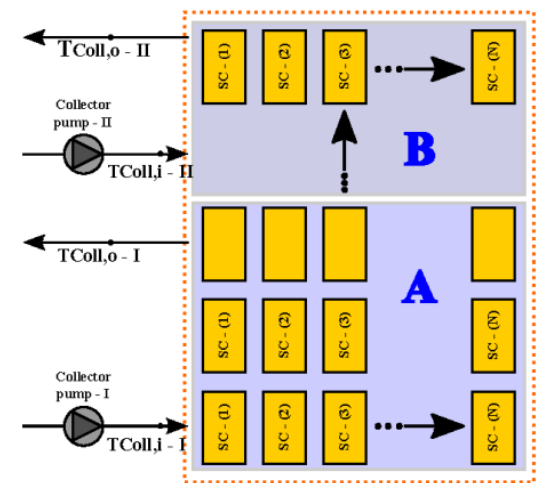

(b) Solar collectors field operation (Field A and Field B)

Fig. 2: The system operation (Solar field)

\subsection{Solar Collectors}

From Fig. 1, the water as a working fluid passing through the solar collectors heat from solar energy and then is directly supplied to the ORC system for power generation [14]. The energy equation from the solar collectors could be calculated from

The solar collector efficiency $\left(\eta_{\text {coll }}\right)$ :

$\eta_{\text {Coll }}=F_{R}(\tau \alpha)_{e}-\frac{F_{R} U_{L}\left(T_{\text {Coll,i }}-T_{A m b}\right)}{I_{T}}$

The useful heat rate from the collectors $\left(\dot{Q}_{\text {coll }}\right)$ :

$\dot{Q}_{\text {coll }}=A_{\text {Coll }}\left[\begin{array}{c}F_{R}(\tau \alpha)_{e} I_{T} \\ -F_{R} U_{L}\left(T_{\text {Coll }, i}-T_{\text {Amb }}\right)\end{array}\right]$

The temperature of water in thermal energy storage $\left(T_{s}^{t+\Delta t}\right)[\underline{15}]$ :

$T_{s}^{t+\Delta t}=T_{s}^{t}+\frac{\Delta t}{M_{S} C_{p}}\left[\begin{array}{c}\dot{Q}_{\text {Coll }}-\dot{m}_{O R C} C_{p}\left(T_{O R C, i}-T_{O R C, o}\right) \\ -U_{A}\left(T_{T E S}-T_{A m b}\right)\end{array}\right]$

Where $T_{A m b}$ is the ambient temperature [14], $I_{T}$ is the solar radiation, $T_{S}^{t+\Delta t}$ and is water temperature at time $t+\Delta t$, and $T_{S}^{t}$ is water temperature at time $t$. 
In this study, 100 to 2,000 units (in 10 units increment) of CPC solar collectors connected in parallel were used for hot water production, having optical efficiency $\left(F_{R}(\tau \alpha)_{e}\right)$ of 0.781 , the overall heat transfer coefficient $\left(F_{R} U_{L}\right)$ of $0.974 \mathrm{~W} / \mathrm{m}^{2}-\mathrm{K}$, and the collectors gross area are $\left(A_{\text {Coll }}\right)$ of $2.160 \mathrm{~m}^{2}$ per unit. Moreover, the TES of 2,500 to 50,000 liters (in 2,500 liters increment) with the overall coefficient of heat loss (UA) was $5 \mathrm{~W} / \mathrm{K}$.

2.2 Organic Rankine Cycle (ORC)

The ORC system operation is similar to the steam Rankine cycle but an organic working fluid is used instead of water. The ORC technology has several advantages such as simple and autonomous operation, low-maintenance, favorable operating pressure, long lifetime (> 20 years) and and no need for demineralizing water. In this study, the performance characteristic of an ORC with the capacity of $60 \mathrm{~kW}_{\mathrm{e}}$ with R-245fa as working fluid (Model: MB-70H [16]) were simulated to find the power output capabilities of the system (shown in Table 1). The testing configuration of the solar collectors integrated with a $60 \mathrm{~kW}_{\mathrm{e}}$ are shown in Fig. 3.

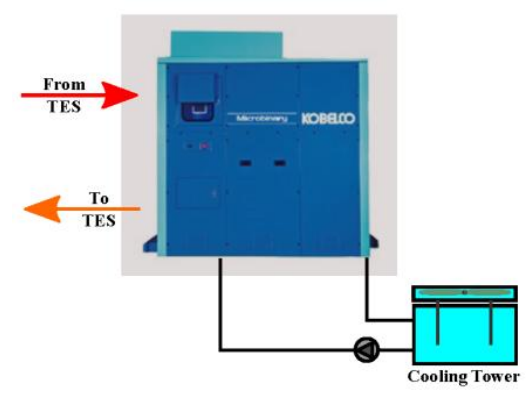

Fig. 3: Model of the solar collectors integrated with a $60 \mathrm{~kW}_{\mathrm{e}}$ ORC power generation

\subsection{Simulation Conditions}

In this study, the weather data from Bangkok represent the central of Thailand as shown in Fig. 4, were taken as the input data for system simulations. In addition, the potential of total solar radiation in Thailand as shown in Fig. 5. Moreover, Hourly global radiation estimation based on the studies of Duffie JA and Beckman WA [17] and Zhang et al. [18] were taken into account. The calculation step as shown in Fig. 6. The system was modelled and evaluated for the number of solar collectors, size of the TES for the maximum power output in each month.

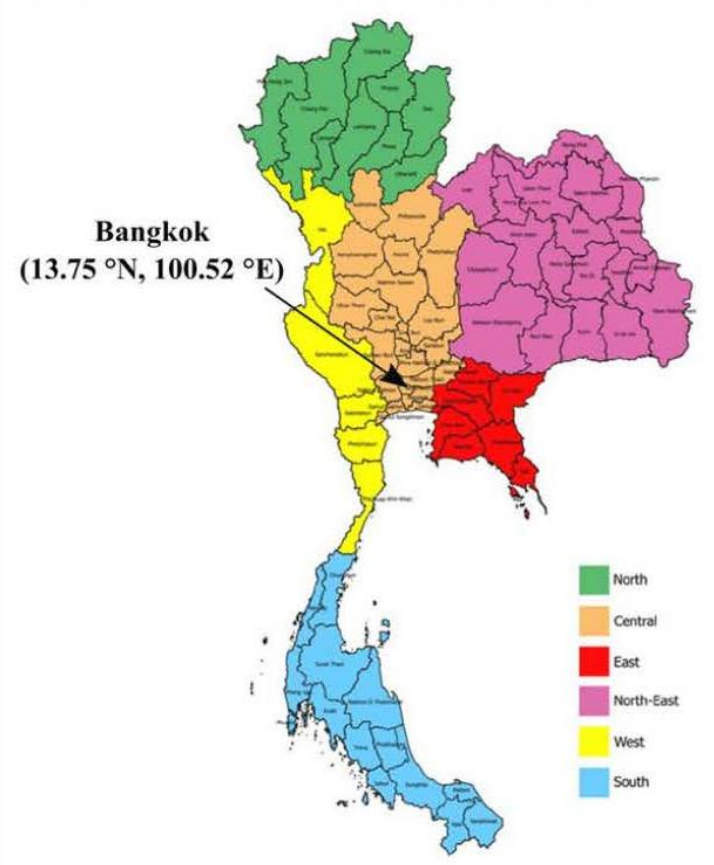

Fig. 4: Location of Bangkok, Thailand 
11

Citation: Sorawit Sonsaree and Eakpoom Boonthum, 2019. A $60 \mathrm{~kW}_{\mathrm{e}}$ Solar Organic Rankine Cycle (SORC) Power Generation in Thailand. Journal of Applied Sciences Research., 15(4): 8-15. DOI: 10.22587/jasr.2019.15.4.2

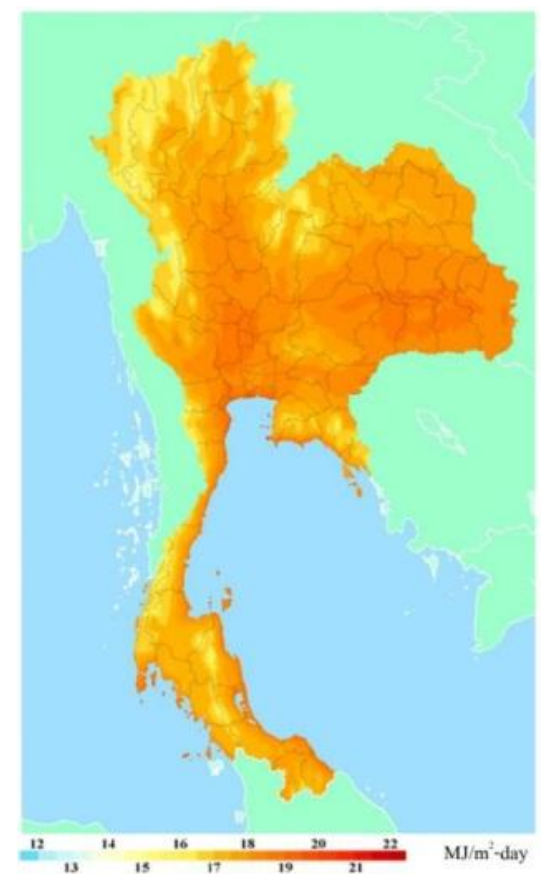

Fig. 5: Potential of total solar radiation in Thailand (MJ/m²-day) [19]

Table 1. The performance characteristic of MB-70H (KOBELCO Company) [16]

\begin{tabular}{|c|c|c|c|c|c|c|c|}
\hline \multirow{2}{*}{$\begin{array}{c}\text { Hot water flow rate } \\
\text { (Ton/h) }\end{array}$} & \multirow{3}{*}{$\begin{array}{c}\text { Cooling water temperature } \\
\left({ }^{\circ} \mathbf{C}\right)\end{array}$} & \multicolumn{6}{|c|}{$\begin{array}{c}\text { Cooling water flow rate } \\
(120 \text { Ton/h) }\end{array}$} \\
\hline & & \multicolumn{6}{|c|}{ Hot water temperature $\left(^{\circ} \mathrm{C}\right)$} \\
\hline & & \begin{tabular}{|c|}
95 \\
\end{tabular} & 90 & 85 & 80 & 75 & 70 \\
\hline \multirow{4}{*}{75} & 15 & 60 & 55 & 47 & 39 & 32 & 24 \\
\hline & 20 & 60 & 52 & 44 & 35 & 28 & 21 \\
\hline & 25 & 57 & 49 & 40 & 32 & 24 & 17 \\
\hline & 30 & 52 & 45 & 36 & 27 & 20 & 14 \\
\hline \multirow{4}{*}{70} & 15 & 59 & 54 & 46 & 38 & 31 & 24 \\
\hline & 20 & 59 & 51 & 43 & 35 & 27 & 20 \\
\hline & 25 & 56 & 48 & 40 & 31 & 24 & 16 \\
\hline & 30 & 51 & 43 & 35 & 27 & 20 & 13 \\
\hline \multirow{4}{*}{60} & 15 & 58 & 51 & 44 & 38 & 31 & 24 \\
\hline & 20 & 57 & 49 & 41 & 33 & 26 & 19 \\
\hline & 25 & 54 & 46 & 38 & 30 & 23 & 16 \\
\hline & 30 & 49 & 41 & 33 & 26 & 19 & 13 \\
\hline \multirow{4}{*}{50} & 15 & 56 & 48 & 42 & 37 & 30 & 23 \\
\hline & 20 & 55 & 48 & 40 & 32 & 25 & 18 \\
\hline & 25 & 52 & 44 & 36 & 29 & 22 & 15 \\
\hline & 30 & 42 & 34 & 28 & 22 & 16 & 11 \\
\hline \multirow{4}{*}{40} & 15 & 51 & 44 & 39 & 33 & 27 & 21 \\
\hline & 20 & 50 & 43 & 36 & 29 & 23 & 17 \\
\hline & 25 & 47 & 39 & 32 & 25 & 19 & 13 \\
\hline & 30 & 42 & 34 & 28 & 22 & 16 & 11 \\
\hline \multirow{4}{*}{30} & 15 & 46 & 40 & 35 & 30 & 24 & 18 \\
\hline & 20 & 45 & 38 & 31 & 25 & 20 & 15 \\
\hline & 25 & 41 & 34 & 28 & 22 & 17 & 12 \\
\hline & 30 & 36 & 29 & 24 & 19 & 14 & 9 \\
\hline \multirow{4}{*}{25} & 15 & 43 & 38 & 33 & 28 & 22 & 17 \\
\hline & 20 & 43 & 35 & 29 & 24 & 19 & 14 \\
\hline & 25 & 38 & 31 & 26 & 20 & 16 & 11 \\
\hline & 30 & 33 & \begin{tabular}{|l|}
27 \\
\end{tabular} & 22 & 17 & 13 & 9 \\
\hline
\end{tabular}




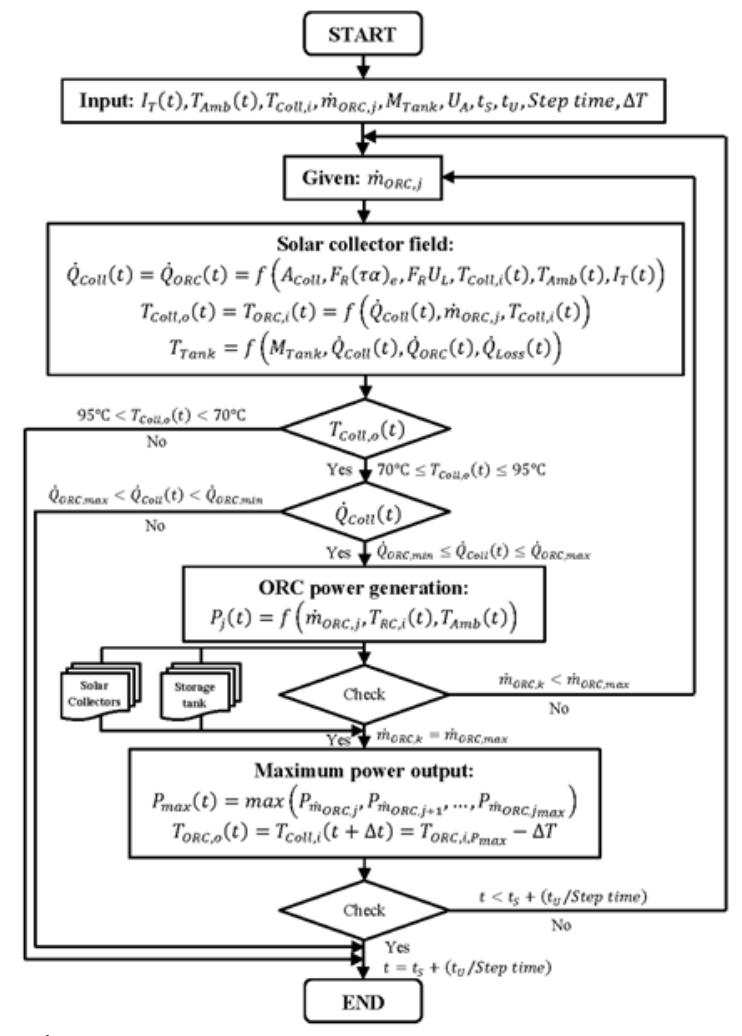

Fig. 6: Calculation step of the SORC power generation

2.4 Economic Analysis

The economic analysis of the integrated system was carried out in terms of the levelized cost of electricity (LCOE) as presen ted in the studies of [20-22], which could be calculated by:

$$
\begin{gathered}
\text { LCOE }=\frac{\mathrm{c} \times\left(C_{\text {Invest }}\right)+\dot{C}_{O \& M}}{\text { Annual Power Output }} \\
c=\frac{i_{d}\left(1+i_{d}\right)^{n}}{\left(1+i_{d}\right)^{n}-1}+k_{\text {insurance }}
\end{gathered}
$$

This is a good indicator that helps to compare other renewable power technologies using the electricity cost (USD/kWh). In this assessment, the investment cost of the ORC power plant was set at around 2,500 USD/kWe [14]. The initial conditions of the system are shown in Table 2.

Table 2. Initial economic conditions of the SORC system

\begin{tabular}{|c|c|}
\hline Descriptions & Data \\
\hline Cost of the CPC solar collectors (USD/m ${ }^{2}$ ) & 196.5 \\
\hline Construction and engineering, $(\%)$ & 10 \\
\hline O\&M cost (percent of investment cost per year) & 5 \\
\hline Insurance rate, $k_{\text {insurance }}(\% /$ year) & 0.6 \\
\hline Real debt interest rate, $i_{d}(\%)$ & 7.325 \\
\hline Depreciation period, $n$ (year) & 25 \\
\hline
\end{tabular}

\section{RESULT AND DISCUSSIONS}

In this study, the SORC power generation with low-temperature heat was proposed and investigated. Their performances in Bangkok, Thailand were mathematically evaluated in terms of power output, $\mathrm{CO}_{2}$ emission, and the $\mathrm{LCOE}$ as shown in the following:

\subsection{Power Output}

The suitable number of solar collectors, size of the TES, and the maximum power output in each month (MWh/Month) are shown in Table 3. The results found that the suitable number of solar collectors which used for produce hot water to supplying to the ORC power generation are 1680 units. Moreover, at the day time (Solar collector Field A), from Jan to Dec the suitable number of solar collectors of 1250, 1160, 1170, 1190, 1482, 1680, 1450, 1650, 1600, 1320, 1020, and 1020 units, and size of the TES of 50000, 47500, 50000, 47500, 47500, 50000, 45000, 50000, 50000, 50000, 32500, and 32500 liters, the system can generated the maximum power output in each month of 10076, 10052, 10199, 10251, 10397, 10575, 10580, 10448, 10253, 9794, 10218, and 10218 MWh/Month, respectively. And the SORC power generation can generated the power output in the day time or sunrise of $123.1 \mathrm{MWh} / \mathrm{Year}$.

Also, at the night time (Solar collector Field B), the power output in each month (MWh/Month) are shown in Table 4. The results found that, from Jan to Dec the number of the solar collectors were not used in the day time of $430,520,510,490,200,0,230,30,80,360,660$, and 660 units, the system can generated the power output in each month of $3649,4893,5339,4174,1643,0,1743,1117,1155,2367,5060$, and $5652 \mathrm{MWh} /$ Month, respectively. And the SORC power generation can generated the power output in the nigh time or sunset of $36.8 \mathrm{MWh} / \mathrm{Year}$.

From the above mentioned, it can be said that the SORC power generation can generate the electricity of $159.9 \mathrm{MWh} /$ Year (Total power output at the day and night time). For more information, the suitable number of the solar collectors, the power output on the day time, nigh time, and all day in each month are shown Fig. 7 to Fig. 10, respectively 
13

Citation: Sorawit Sonsaree and Eakpoom Boonthum, 2019. A $60 \mathrm{~kW}_{\mathrm{e}}$ Solar Organic Rankine Cycle (SORC) Power Generation in Thailand. Journal of Applied Sciences Research., 15(4): 8-15. DOI: 10.22587/jasr.2019.15.4.2

Table 3. Power output at the suitable number of the collector and the TES (Day time: Solar collector field A)

\begin{tabular}{|c|c|c|c|c|c|}
\hline \multirow{2}{*}{ Month } & Collectors & Tank & \multicolumn{3}{|c|}{ Power output } \\
\cline { 2 - 7 } & (Unit) & (Liters) & $(\mathbf{k W h} / \mathbf{D a y})$ & $\mathbf{( k W h / M o n t h )}$ & (MWh/Month) \\
\hline Jan & 1250 & 50000 & 325 & 10076 & 10.1 \\
\hline Feb & 1160 & 47500 & 324 & 10052 & 10.1 \\
\hline Mar & 1170 & 50000 & 329 & 10199 & 10.2 \\
\hline Apr & 1190 & 47500 & 331 & 10251 & 10.3 \\
\hline May & 1480 & 47500 & 335 & 10397 & 10.4 \\
\hline Jun & 1680 & 50000 & 341 & 10575 & 10.6 \\
\hline Jul & 1450 & 45000 & 341 & 10580 & 10.6 \\
\hline Aug & 1650 & 50000 & 337 & 10448 & 10.4 \\
\hline Sep & 1600 & 50000 & 331 & 10253 & 10.3 \\
\hline Oct & 1320 & 50000 & 316 & 9794 & 9.8 \\
\hline Nov & 1020 & 32500 & 330 & 10218 & 10.2 \\
\hline Dec & 1020 & 32500 & 330 & 10218 & 10.2 \\
\hline \multicolumn{5}{|c|}{ Total (MWh/Year) } \\
\hline \multicolumn{5}{|c|}{} \\
\hline
\end{tabular}

Table 4. Power output at the night time (Solar collector field B)

\begin{tabular}{|c|c|c|c|c|}
\multirow{2}{*}{ Month } & Collectors & \multicolumn{3}{|c|}{ Power output } \\
\cline { 2 - 5 } & (Unit) & $\mathbf{( k W h / D a y ) ~}$ & $\mathbf{( k W h / M o n t h )}$ & (MWh/Month) \\
\hline Jan & 430 & 118 & 3649 & 3.6 \\
\hline Feb & 520 & 175 & 4893 & 4.9 \\
\hline Mar & 510 & 172 & 5339 & 5.3 \\
\hline Apr & 490 & 139 & 4174 & 4.2 \\
\hline May & 200 & 53 & 1643 & 1.6 \\
\hline Jun & 0 & 0 & 0 & 0.0 \\
\hline Jul & 230 & 56 & 1743 & 1.7 \\
\hline Aug & 30 & 36 & 1117 & 1.1 \\
\hline Sep & 80 & 39 & 1155 & 1.2 \\
\hline Oct & 360 & 76 & 2367 & 2.4 \\
\hline Nov & 660 & 169 & 5060 & 5.1 \\
\hline Dec & 660 & 182 & 5652 & 5.7 \\
\hline \multicolumn{5}{|c|}{ Total (MWh/Year) } \\
\hline
\end{tabular}

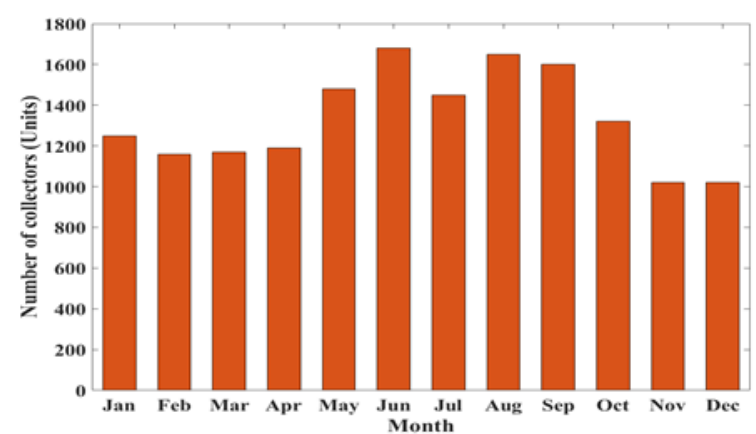

Fig. 7: Suitable number of solar collectors in each month

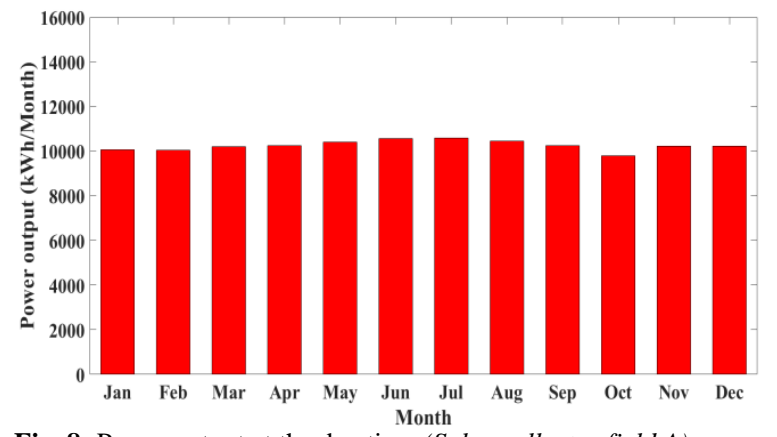

Fig. 8: Power output at the day time (Solar collector field A) 


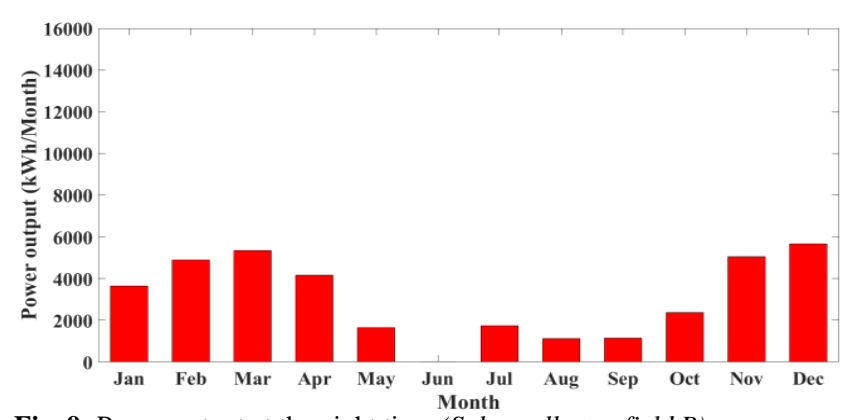

Fig. 9: Power output at the night time (Solar collector field B)

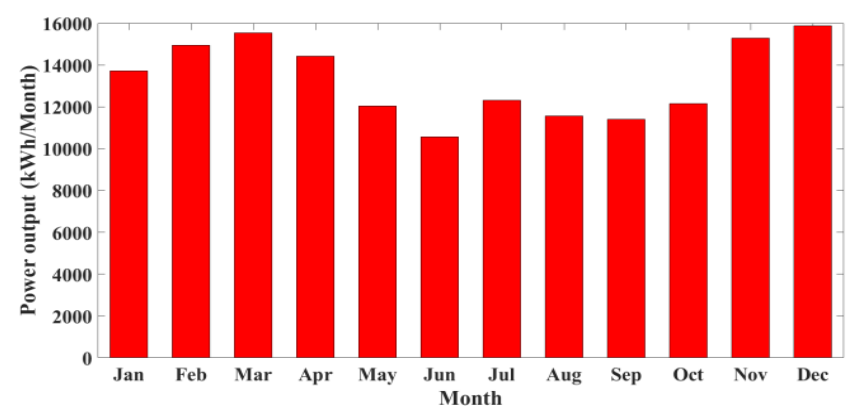

Fig. 10: Total power output in each month (Day and Night time)

\subsection{Environment Evaluation}

To estimate $\mathrm{CO}_{2}$ emission, carbon dioxide intensity factor in Thailand of $0.548 \mathrm{~kg} \mathrm{CO}_{2}$ eq./kWh [12] is considered. The results found that, the quantity of $\mathrm{CO}_{2}$ emission that the system can decrease depends on the electricity production. The total power output from Table 3 and Table 4 can be estimate $\mathrm{CO}_{2}$ emission by multiply the carbon dioxide intensity factor as shown in Table 5 and Fig. 11. It also showed that from Jan to Dec the system can reduce $\mathrm{CO}_{2}$ emission of 7521 , $8190,8515,7905,6598,5795,6753,6337,6252,6664,8372$, and $8697 \mathrm{~kg} \mathrm{CO}_{2}$ eq., respectively, and the total $\mathrm{CO}_{2}$ emission the system can reduce of $88 \mathrm{Ton} \mathrm{CO}_{2}$ eq./Year.

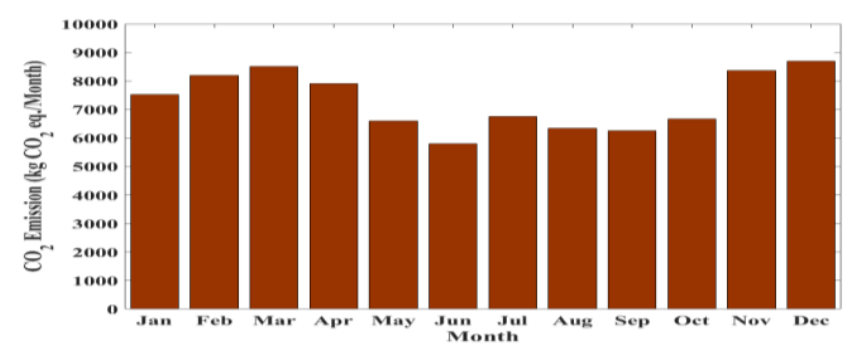

Fig. 11: $\mathrm{CO}_{2}$ Emission in each month ( $\mathrm{kg} \mathrm{CO}_{2}$ eq./Month)

Table 5. $\mathrm{CO}_{2}$ Emission in each month of the SORC system

\begin{tabular}{|c|c|c|}
\hline \multirow{2}{*}{ Month } & Power output & $\mathbf{C O}_{\mathbf{2}}$ Emission \\
\cline { 2 - 3 } & (kWh/Month) & $\mathbf{( k g}_{\mathbf{~ C O}} \mathbf{~ e q .}$. \\
\hline Jan & 13725 & 7521 \\
\hline Feb & 14945 & 8190 \\
\hline Mar & 15538 & 8515 \\
\hline Apr & 14425 & 7905 \\
\hline May & 12040 & 6598 \\
\hline Jun & 10575 & 5795 \\
\hline Jul & 12323 & 6753 \\
\hline Aug & 11565 & 6337 \\
\hline Sep & 11408 & 6252 \\
\hline Oct & 12161 & 6664 \\
\hline Nov & 15278 & 8372 \\
\hline Dec & 15870 & 8697 \\
\hline \multicolumn{2}{|c|}{ Total (Ton $\mathbf{C O}_{2}$ eq./Year) } & $\mathbf{8 8}$ \\
\hline
\end{tabular}

\subsection{Economic Evaluation}

In this assessment, the initial investment of the solar collectors and the ORC power generation are considered for the SORC power plant. From Table V, the results was found that when the government was not supported the investment cost, the LCOE of the system was 0.9105 USD/kWh (0\% Government supported). However, when the government was supported, the LCOE of the system become more interesting. From the TABLE 6, when the government supported 25, 50, and $75 \%$ of the investment cost. The LCOE of the system of $0.7030,0.4954$, and $0.2879 \mathrm{USD} / \mathrm{kWh}$, respectively.

As consider the Concentrating Solar Power (CSP) and Photovoltaic technologies are applied for electrical power, the LCOE is between 0.14 and 0.36 USD/kWh [12], and between 0.25 and $0.71 \mathrm{USD} / \mathrm{kWh}$ [12], respectively. Therefore, the SORC power system is not interesting due to the high LCOE. However, when the government was supported the investment around 50\%, a lower LCOE can be achieved around 0.4954 USD/kWh. Then, the system becomes more interesting, when the systems are subsidized by the government. 
Citation: Sorawit Sonsaree and Eakpoom Boonthum, 2019. A $60 \mathrm{~kW}_{\mathrm{e}}$ Solar Organic Rankine Cycle (SORC) Power Generation in Thailand. Journal of Applied Sciences Research., 15(4): 8-15. DOI: 10.22587/jasr.2019.15.4.2

\begin{tabular}{|c|c|c|c|}
\hline Government supported & Collector cost & ORC cost & LCOE \\
\hline$(\%)$ & (USD/m $\left.^{2}\right)$ & $\left(\mathbf{U S D} / \mathbf{k} \mathbf{W}_{\mathbf{e}}\right)$ & $(\mathbf{U S D} / \mathbf{k W h})$ \\
\hline 0 & 196.49 & 2500 & 0.9105 \\
\hline 25 & 147.37 & 1875 & 0.7030 \\
\hline 50 & 98.25 & 1250 & 0.4954 \\
\hline 75 & 49.12 & 625 & 0.2879 \\
\hline
\end{tabular}

\section{CONCLUSIONS}

In this study, a concept of the SORC power plant applied for low-temperature heat $\left(<100{ }^{\circ} \mathrm{C}\right)$ was proposed and investigated. CPC collectors are used to upgrade the heat before supplying to the system. The system was mathematically modeled and simulated under the climate of Bangkok, to investigate the maximum power output, the impact on the environment, and the economic analysis in terms of levelized cost of electricity (LCOE). It can be summarized as follows:

The SORC power plant is a good solution for power generation from low-temperature heat source.

The LCOE of the SORC power plant was the lowest of $0.9105 \mathrm{USD} / \mathrm{kWh}$, power output of $159.9 \mathrm{MWh} / \mathrm{Year}$, and reduce $\mathrm{CO}_{2}$ emission of $88 \mathrm{Ton} \mathrm{CO}_{2}$ eq./Year.

The system becomes more interesting, when the government supports or subsidies the investment of collectors, and the ORC system.

In future works, the proposed system may become more interesting if a power plant that operates 24 hours per day, by integration of an industrial process heat or other renewable sources such as biomass is developed.

\section{Acknowledgment} Thailand.

This work was supported by the Institution of Research and Development, and Faculty of Industrial Technology, Pibulsongkram Rajabhat University,

\section{Authors' Contribution}

Dr. Sorawit Sonsaree developed the idea, the mathematical model and had an important role in the result and material section. Mr. Eakpoom Boonthum performed the statistical analysis, the discussion and the abstract submission.

\section{Financial Disclosure}

This work was financially supported by the Pibulsongkram Rajabhat University's Personal Development Fund of Thailand.

\section{Funding/Support}

No financial assistance was obtained from any organization or company. The project was funded by the institution itself.

[1] Giostri, A., et al., Comparison of different solar plants based on parabolic trough technology. Solar Energy, 2012.86 : p. $1208-1221$.

[2] Potentials of Concentrating Solar Power Technologies in Thailand. 2006, Department of Alternative Energy Development and Efficiency (DEDE), Ministry of Energy.

[3] IEA, RENEWABLES FOR POWER GENERATION Status \& Prospects 2003 Edition. 2017, International Energy Agency.

[4] Domínguez Bravo, J., X. García Casals, and I. Pinedo Pascua, GIS approach to the definition of capacity and generation ceilings of renewable energy technologies. Energy Policy, 2007. 35(10): p. 4879-4892.

[5] Ishan, P. and P. Pallav, Techno-economic evaluation of concentrating solar power generation in India. Energy Policy, 2010. $38(6)$ : p. $3015-3029$.

[6] Wang, J., et al., Off-design performance analysis of a solar-powered organic Rankine cycle. Energy Conversion and Management, 2014.80 : p. 150-157.

[7] Mavrou, P., et al., Novel and conventional working fluid mixtures for solar Rankine cycles: Performance assessment and multi-criteria selection. Applied Thermal Engineering, 2015. 75: p. 384-396.

[8] Garg, P., M.S. Orosz, and P. Kumar, Thermo-economic evaluation of ORCs for various working fluids. Applied Thermal Engineering, 2016. 109: p. 841853.

[9] Quoilin, S. and V. Lemort. Technological and Economical Survey of Organic Rankine Cycle Systems. in 5th EUROPEAN CONFERENCE ECONOMICS AND MANAGEMENT OF ENERGY IN INDUSTRY. 2009.

[10] Sylvain, Q., et al., Techno-economic survey of Organic Rankine Cycle (ORC) systems. Renewable and Sustainable Energy Reviews, 2013.22 : p. 168-186.

[11] Wang, M., et al., Thermodynamic analysis and optimization of a solar-driven regenerative organic Rankine cycle (ORC) based on flat-plate solar collectors. Applied Thermal Engineering, 2013. 50(1): p. 816-825.

[12] Sonsaree, S., et al., A small-scale solar Organic Rankine Cycle power plant in Thailand: Three types of non-concentrating solar collectors. Solar energy, 2018. 162: p. 541-560.

[13] Spayde, E., P.J. Mago, and R. Luck, Economic, Energetic, and Environmental Performance of a Solar Powered Organic Rankine Cycle with Electric Energy Storage in Different Commercial Buildings. Energies, 2018. 11(2): p. 276.

[14] Sonsaree, S., et al., VCHP-ORC Power Generation from Low-Grade Industrial Waste Heat Combined with Solar Water Heating System: Power Generation and $\mathrm{CO}_{2}$ Emission in Industrial Estate of Thailand. Cogent Engineerings, 2017. 4(1).

[15] Thawonngamyingsakul, C. and T. Kiatsiriroat, Potential of a solar organic rankine cycle with evacuated-tube solar collectors as heat source for power generation in Thailand. Energy Science and Technology, 2012. 4(2): p. 25-35.

[16] KOBELCO. 2017.

[17] JA, D. and B. WA, Solar engineering of thermal processes. 2013, Hoboken, New Jersy: John Wiley \& Sons, Inc.

[18] Zhang, J., et al., A critical review of the models used to estimate solar radiation. Renewable and Sustainable Energy Reviews, 2017.70 : p. 314-329.

[19] Potential of solar energy in Thailand. 2019: Department of Alternative Energy Development and Efficiency (DEDE).

[20] Chaiyat, N. and T. Kiatsiriroat, Analysis of combined cooling heating and power generation from organic Rankine cycle and absorption system. Energy, 2015. 91: p. 363-370.

[21] Chaiyat, N., Sustainability of Alternative Energy for Organic Rankine Cycle Power Plant in Thailand. Naresuan University Journal: Science and Technology, 2015. 23(1): p. 45-62.

[22] Pitz-Paal, R., J. Dersch, and B. Milow, European Concentrated Solar Thermal Road-Mapping. 2003. 